\title{
AVISO
}

Por no disponer de los correspondientes originales informáticos, la maquetación de este artículo difiere de la del publicado en papel. Por lo demás, los contenidos no han sufrido ninguna alteración.

Artículo publicado en el fascículo $2^{\circ}$ del tomo LXV (1997) de EMERITA, pp. 195-220

Autor: Gaspar Morocho Gayo

\section{HERMENÉUTICA Y FILOLOGÍA EN EL CONTEXTO DE DIÓN DE PRUSA*}

In Dio of Prusa's (ca. 40-120 AD) Speech on Homer (Or. LIII,1-5) we find a brief history of textual interpretation. When referring to Democritus Dio draws from the doxographic tradition. For the sophist from Prusa grammarians activity originates from Aristotle and the peripatetic school. The author shall study the characteristics of Alexandrian philology and the discussion - ignored by Dio - arisen from Dionysius Trax's definition, which lasted until the second century AD. Then he shall be concerned with the different kinds of hermeneutics enumerated or alluded to in the already mentioned passage, paying special attention to the cynic-stoic hermeneutics practised by the sophist.

\section{Consideración preliminar.}

Los antiguos griegos fueron, como en otros campos del saber, los verdaderos creadores de la hermenéutica en todas sus modalidades. Desde el siglo VI a C. se crearon en Grecia diversos modelos de hermenéutica, basados en diversas formas de alegoría física, ética o moral, o exégesis histórica. Pero no voy a insistir en la definición o ejemplificación de todas estas formas de exégesis, muy bien estudiadas en los últimos años ${ }^{1}$. Baste decir que un mismo relato o un mismo personaje mítico podían ser interpretados bajo la forma de exégesis física, ética, o histórica, según fueran identificados como fenómenos o fuerzas de la naturaleza, personificaciones de vicios o virtudes, o con un personaje histórico o fenómeno geográfico. Las aparentes antinomias que a veces aparecen en los autores pueden derivar de la diversidad de estas formas exegéticas.

Estas interpretaciones diversas nacieron como reacción o desarrollo de

* Este estudio ha sido realizado dentro del Proyecto «Humanistas Españoles. Estudios y ediciones críticas», subvencionado por la Dirección General de Investigación Científica y Técnica (P-B 93-0062).

1 Véanse los trabajos ya clásicos como los de F. Buffière sobre Les Mythes d' Homère et la pensée grecque, Paris, 1956, obra resumida en la Introduction de su edición de Héraclite, Allegories d' Homère, (Paris, 1962). 
una hermenéutica racionalista, iniciada por Jenófanes de Colofón y otros pensadores de la filosofía jonia. Más tarde Platón y Aristóteles crearon, a partir de sus teorías del conocimiento, un sistema muy elaborado de hermenéutica. A partir del siglo I p. C. aparecieron sistematizadas las leyes de estas formas de hermenéutica tradicional. Así por ejemplo las Homericae Allegoriae del Pseudo-Heráclito o los escritos de Cornuto y Paléfato ${ }^{2}$. A partir de la segunda Sofística surgieron otras formas nuevas de interpretación, ligadas a la teología que se inició con Plutarco o bien la llamada exégesis mística del neoplatonismo y neopitagorismo tardíos, de gran incidencia en autores de la literatura tardoantigua, incluida la de los escritores cristianos $^{3}$. Muchos textos y representaciones artísticas se escriben o plasman en clave de alegorías, de acuerdo con las leyes de la naturaleza, del enigma o del misterio.

El estudio de la hermenéutica griega sirve, por lo tanto, para interpretar y explicar obras literarias y manifestaciones culturales y artísticas del mundo greco latino. Pero, sobre todo, resulta imprescindible su estudio para una correcta interpretación del pensamiento, literatura y arte de la Edad Media bizantina, y del Humanismo renacentista de Europa occidental.

Creo que puede ser de interés el estudio de los autores griegos y latinos de la época imperial y tardía, para entender mejor la literatura europea de la Edad Media y del Renacimiento. Dión vive en un mundo en que la imitación o reinterpretación de los clásicos es ya un recurso ulterior al «postmodernismo» de su tiempo.

La búsqueda de la verdad por parte de los escritores de la segunda sofística y de los siglos IV-V condiciona en gran medida la literatura posterior. En efecto, fueron los procedimientos de técnica retórica y hermenéutica tardoantiguos los que mayormente influyeron en las formas de composición literaria de los periodos siguientes, hasta el llamado siglo de las luces.

2 Paléfato, a finales del siglo IV a. C., escribió una obra Sobre lo increíble, en la que hace un intento de racionalización de los antiguos mitos. Mayor influjo tuvo en la Antigüedad el Compendio de teología griega de Lucio Anneo Cornuto. Cf. ed. de C. Lang, Cornuti Theologiae compendium, Leipzig, Teubner 1881, así como el estudio de R. S. Hays, Lucius Anneus Cornutus. Epidrome. Introduction to the Traditions of Greek Theology, Diss. University of Texas, 1983.

3 Bibliografía sobre estos autores en A. B. Hersman, Studies in Greek Allegorical Interpretation, Diss. Chicago, 1906.

EMERITA. Revista de Lingüística y Filología Clásica (EM) - LXV 2, 1997, pp. 195-220 
La gran aceptación que tuvieron los escritores de la Antigüedad tardía hasta el siglo XVII, contrasta notablemente con el descrédito y rechazo a que se vieron sometidos a partir del XVIII. Para los pensadores y filólogos del romanticismo y de una gran parte del siglo XX, incluso en los manuales de Historia de la literatura griega, estos autores no son otra cosa que un «museo de fósiles». Así los define la voluminosa obra de W. von Christ-W. von Schmidt-O. Sthälin ${ }^{4}$. En libros más modernos, que leíamos los estudiantes de mi generación, como era el clásico manual de $\mathrm{A}$. Lesky ${ }^{5}$ o el de R. Cantarella, se afirma, por ejemplo en este último, que «la segunda sofística no es un movimiento de pensamiento, ni tampoco de cultura, es únicamente el apogeo que asume la retórica al convertirse en un fenómeno social, pero sin aportar ninguna innovación a la enseñanza ni a las corrientes tradicionales $»^{6}$

En el fondo y en la forma, ésta es la cosmovisión estética del siglo XIX y de una gran parte del XX. No obstante, estudios y monografías como los de Reardon $^{7}$, Bompaire ${ }^{8}$, Caster ${ }^{9}$, Boulanger ${ }^{10}$, Bowie ${ }^{11}$, Bowersock ${ }^{12}$, Luis

4 Geschichte der griechischen Literatur, II (1-2), Munich, Beck, 1948, reimpr., 1959, ss.

5 Historia de la Literatura Griega, Gredos, 1968. Sobre otros manuales más recientes de historia de la literatura griega cf. J.A. López Férez (Ed.), Historia de la Literatura Griega, Madrid, 1988; P. E. Easterling \& B.M.W. Knox, Historia de la Literatura Clásica I. Literatura Griega, Madrid, 1990.

$6 \quad$ Storia de la letteratura greca, Milán, Nuova Academia, trad. española en dos vols.; citamos por el II: La literatura griega de la época helenística e imperial, Buenos Aires, Losada, 1972, p. 293.

7 Courants littéraires grecs des II et III siècles après J.-C., París 1971.

8 Lucien écrivain, Paris, 1958.

$9 \quad$ Lucien et la pensée religieuse de son temps, Paris, 1937.

10 Aelius Aristides et la sophistique dans la province d' Asie au II siècle de notre ère, Paris, 1923.

11 «Greek and their Past in the Second Sophistic», Past and Present, XLVI, 1970, 3-41, recogido por M.I. Finley (ed), Studies in Ancient Society, London-Boston, 1974, 166-209. Trad. española de R. López con el título Estudios sobre Historia Antigua, Madrid 1981, pp. 185-231; cf. además «The Importance of Sophists», YCLS 27, 1982, pp. 29-60.

12 Greek Sophists in the Roman Empire, Oxford, 1969: y del mismo autor Approaches to the Second Sophistic, University Park, Pennsylvania, 1974.

EMERITA. Revista de Lingüística y Filología Clásica (EM) - LXV 2, 1997, pp. 195-220 
Gil $^{13}$, Díaz Tejera ${ }^{14}$ y E. A. Ramos Jurado ${ }^{15}$, comenzaron a ver en la segunda sofística y en autores más tardíos una reinterpretación de los autores clásicos, que partiendo de la retórica y de la controversia entre aticistas y asianistas, trató de revivir el esplendor literario y cultural de los grandes clásicos del pasado. Es decir, la segunda sofística es ya una cierta forma de humanismo, que servirá como paradigma al renacimiento literario de los siglos IV y V, y de modelo a los renacimientos posteriores.

\section{Historia de la exégesis homérica en Dión de Prusa, Or. LIII, 1-5.}

Estudia Dión en este pasaje las principales formas de hermenéutica desde la Antigüedad hasta su tiempo, con referencia a las distintas escuelas filosóficas y especial mención a la filología ${ }^{16}$. Siete son las principales modalidades que reseña el Sofista, aunque indudablemente las formas de hermenéutica habían sido muchas más. Dión establece una distinción entre la exégesis que deriva de la gramática filológica y de la crítica literaria, y aquellas otras formas de hermenéutica homérica anteriores a su tiempo. El conocimiento de las formas de exégesis que pertenecen a la hermenéutica resulta tan necesario para un filólogo y estudioso de Dión como el conocimiento de la retórica clásica ${ }^{17}$, a la cual suelen estar ligadas.

De otro lado nuestro autor diferencia claramente las formas de exégesis que pertenecen a sistemas racionalistas (Platón y Aristóteles) de aquellas otras que se buscan una defensa de Homero ya sea del mensaje religioso de los poemas homéricos. La hermenéutica trataba de evitar las aparentes

13 «El cinismo y la remodelación de los arquetipos culturales griegos», Revista de la Universidad Complutense N.S. 1, 1980, pp. 43-78.

14 El pensar simbólico y el fenómeno cultural. Discurso leído en la Real Academia de Buenas Letras, Sevilla, 1987.

15 Enrique A. Ramos Jurado, Lo Platónico en el siglo V p. C.: Proclo, Publicaciones de la Universidad de Sevilla, 1981.

16 Sobre los presupuestos dioneos y los tipos más habituales de la exégesis nos hemos ocupado en: «Formas de exégesis y reinterpretación de Arquetipos en Dión de Prusa», Caesura 3, 1993, pp. 63-87. Una bibliografía sobre Dión de Prusa en Estudios de Drama y Retórica en Grecia y Roma, Universidad de León, 1987, pp. 354-364, con posterioridad B. F. Harris ha publicado «Dion of Prusa: A survey of Recent Works», ANRW 33, 1991, pp. 3853-3881.

17 Un buen planteamiento en la obra dionea es el estudio de P. Desideri, «Tipologia e varietà di funzione comunicativa degli scritti dionei», ANRW 33, 1991, pp. 3903-3959.

EMERITA. Revista de Lingüística y Filología Clásica (EM) - LXV 2, 1997, pp. 195-220 
contradicciones de los poemas homéricos, buscando significaciones subyacentes, alegóricas, enigmáticas, etc. con explicaciones de índole filosófica y teológica. El Sofista de Prusa pretende conciliar, bajo el denominador común de la interpretación homérica, a filósofos de diferentes tendencias, gramáticos alejandrinos y críticos literarios de la escuela de Pérgamo, silenciando los acalorados debates que tenían lugar en su tiempo. Asimismo, de acuerdo con una tendencia sincretista que tendrá una gran fortuna a finales de la Antigüedad no establece fronteras claras entre cinismo y estoicismo. El Prusense limita su enumeración a los autores o sistemas más representativos ${ }^{18}$.

La exégesis de Dión presupone un incipiente sincretismo de cinismo y estoicismo, que con otros sistemas filosóficos y diversas formas de religiosidad griega, acabará confluyendo a finales de la Antigüedad, en una forma de monoteísmo inmanente a este mundo. Este monoteísmo inmanente frente al Dios personal y trascendente de la tradición judeocristiana está integrado por todo un conglomerado filosófico que impropiamente ha sido englobado en la denominación genérica de neoplatonismo. Pero en este conglomerado han confluido por sincretismo corrientes tan diversas como la filosofía peripatética, el estoicismo, pitagorismo, orfismo, cinismo y, sobre todo, platonismo en su vertiente de neoplatonismo propiamente dicho.

Resulta pertinente considerar la hermenéutica dionea a partir de la concepción de un Poder único que rige el universo ${ }^{19}$. Esta concepción de la divinidad aparece nítidamente expresada en el Olímpico y en el Boristénico y va mucho más allá del dios estoico tradicional, constituyendo una de las expresiones más altas que sobre la pureza divina nos legó la Antigüedad ${ }^{20}$.

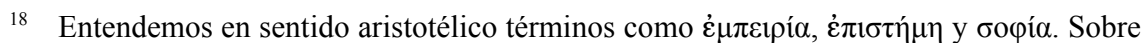
la definición de estos conceptos cf. Arist. Metaph. 981a1 - 982 a3. EN 1139b 14, ss.

19 D. Chr. I 42-38.

20 En ambos discursos Dión habla desde la madurez de sus meditaciones religiosas. Por eso, me inclino a pensar en una fecha de composición posterior al año 100 de nuestra Era como término ante quem en la composición del Olímpico. El Boristénico es tal vez uno de los últimos ensayos del prusense. Parece como si el autor, sin perder de vista los principios de la filosofía estoica, que ha practicado durante una gran parte de su existencia, volviera los ojos a la religión de su tierra natal y de su patria, vinculada a los cultos mistéricos de Cibeles cf. B. F. Harrison, «The Olympian Oratio of Dio Chrysostom», Journ. Rel. Hist. 2, 1962, pp. 85-97; I. Chirassi, «Il significato religioso del XII discorso di Dione di Prusa», RCCM 5, 
Tal vez este hecho pueda explicarse por el conocimiento de diversas religiones mistéricas ${ }^{21}$, que prometían la salvación individual e incluso de formas de vida como la de los esenios entre los cuales se ha dicho que Dión había pasado algún tiempo ${ }^{22}$. No obstante, para el pensador de Prusa, cuyo mensaje está lleno de grandes sutilezas sofísticas y retóricas, el verdadero centro del debate radica en los dilemas de verdad y engaño, como nos desvela en el proemio del Troyano ${ }^{23}$.

Existen, además, otras dos coordenadas que son como prerrequisitos fundamentales para conocer el alcance de la exégesis de Dión: su concepción del mundo y de la vida del hombre. El Sofista de Prusa, como Séneca de

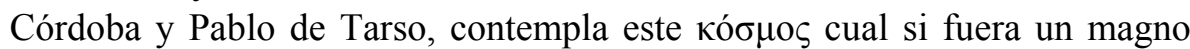

1963, pp. 266-285.

21 Existe una alusión a los cultos mistéricos de Cibeles, cuando refiere el episodio de la sacerdotisa en el Discurso I de la Realeza, la cual le predice en los montes de Arcadia el fin de su destierro y el advenimiento de un principe ideal que será el español Trajano, a quien Dión refiere su relato (D. Chr. I 50-57). En el Himno al sol de Zoroastro y los magos persas que leemos en el Boristénico, detrás de los cuales parece que se esconden los sacerdotes de Mitra, Dión va más allá de la concepción religiosa del estoicismo, y creo que no sin razón, algunos intérpretes, como Bidez-Cumont, Les mages hellénises, Paris, 1938, vid. ad loc., han percibido en este Himno ecos de una concepción religiosa oriental.

22 G. Morocho Gayo, Dión de Prusa. Discursos I-XI, Madrid, 1988, p. 36 n. 36 De ser cierta, su estancia entre los esenios, habría que decir que no es nuevo en Dión de Prusa el afán de evasión y escapismo que leemos en algunos ensayos tan significativos como el Euboico, cf. H. Hommel, «Dio Chrysostomos euboische Idylle» WHB 4, 1961, pp. 18-21. No obstante, estos viajes a tierras remotas y lugares apartados pueden tener antecedentes literarios muy claros en relatos como el mito de la edad de oro, en las utopías de Platón o en la Meropia de Teopompo, hoy perdida. El Euboico de Dión, cuya primera parte está construida en técnica de novella es un canto lírico, escrito en prosa, a la vida sencilla y retirada de unos pastores, que han elegido la soledad de las montañas para vivir de acuerdo con la naturaleza frente al bullicio y corrupción moral de la urbe. A estas gentes sencillas el retiro en las montañas les ayuda a encontrar las respuestas que afligen a la existencia humana.

23 D. Chr. XI 1-10. El Troyano es, además, una de las mejores obras de crítica literaria de toda la Antigüedad. Fue impreso varias veces durante el Humanismo italiano y el Renacimiento europeo, como hemos escrito en otro lugar: «Traducciones de Dión de Prusa», Fidus Interpres, J. Santoyo \& alii (eds.), vol.II, León, 1989, pp. 154-163; «Diego Gracián y sus versiones de clásicos Griegos», Ibidem, pp. 353-363. Sobre su problemática cf. W. A. Montgomery, Dio Chrysostom as a Homer Critic, Baltimore, 1901; M. Szarmach, «Le discours Troyen de Dion de Pruse», Eos 66, 1978, pp. 195-202; G. A. Seeck, «Dion Chrysostomos als Homer Kritiker (Or. 11)», RhM 133, 1990, pp. 97-107.

EMERITA. Revista de Lingüística y Filología Clásica (EM) - LXV 2, 1997, pp. 195-220 
estadio y concibe la vida humana como un certamen agonal, en el que la meta no es la conquista de una corona de apio, de olivo, de pino o de laurel, sino la obtención de la virtud, cuyo premio es la felicidad ${ }^{24}$. Todos ellos tienen una concepción ascética de la vida como lo demuestran las coincidencias formales de metáforas deportivas y de catálogos idénticos de vicios y virtudes. Consecuentemente, según Dión, el hombre no puede

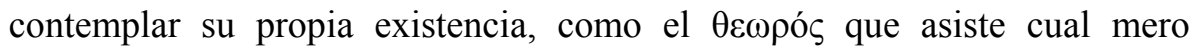

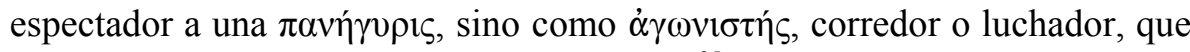
se lanza a la arena del estadio de este $\kappa o ́ \sigma \mu o \varsigma^{25}$.

\section{Los llamados «escritos filológicos» de Demócrito de Abdera.}

El Sofista comienza su desarrollo alabando el pensamiento de Demócrito, porque admitía la inspiración divina en la composición de la poesía homérica $^{26}$. Dión en este pasaje se limita a comentar una máxima de la tradición doxográfica, bien atestiguada en Cicerón ${ }^{27}$, Horacio $^{28} \mathrm{y}$,

24 Dio Prus. Or. VIII 15 cf. H. Funke, «Antisthenes bei Paulus», Hermes 98, 1970, 459-471 Estos elementos comunes han de ser interpretados como ideas propias del ambiente y de la época, tópicos habituales de una prédica popular no bien conocida, a partir de la cual motivos y formas infraliterarias pasan al plano de la literatura, un fenómeno que ocurre en todas las épocas. También se fundamenta esa coincidencia formal y de contenido en la unidad de programas escolares vigentes en los más prestigiosas escuelas del Imperio, «Tecnica della predicazione popolare: cenni di oratoria dionea», en P. Desideri, Dione di Prusa. Un intellettuale greco nell' Impero romano, Messina - Firenze, 1978, pp. 469-523.

25 R. Joly, Remarque sur Dion Chrysostome et le Nouveau Testament, Assen, 1975; G. Mussies, Dio Chrysostomos and the New Testament, Leiden, 1972 .

26 D. Chr. LIII 1.

27 Poetam bonum neminem ... sine inflamatione animorum existere posse et sine quodam adflatu quasi furoris, cf. de oratore, II 46, 194 (= DK 68, B 17). En otro pasaje, de diuin. I 38, 80, (= DK 68 B 17), dice: negat enim sine furore Democritus quemquam poetam magnum esse posset. Sin embargo, Cicerón atribuye también este dicho a Platón de oratore, I 49 (=DK 68, A, 34). También en DK 68 A, 34 se recogen otros dos testimonios de Cicerón sobre el estilo de Demócrito. Las enseñanzas de los dos filósofos eran coincidentes en la descripción de las cualidades del ritmo, en el que han de resplandecer «los brillantísimos destellos del lenguaje», de oratore, I 49. La atribución a Platón y a Demócrito de la misma doctrina plantea el difícil problema de la primacía y autenticidad.

${ }_{28}$ Ingenium misera quia fortunatius arte credit et excludit sanos Helicone poetas, cf. de arte poetica, 295 (= DK 68 B 17).

EMERITA. Revista de Lingüística y Filología Clásica (EM) - LXV 2, 1997, pp. 195-220 
posteriormente, en Clemente de Alejandría ${ }^{29}$. El Prusense no atestigua explícitamente la existencia de un tratado de Demócrito Sobre Homero, cuya noticia conocemos por Diógenes Laercio ${ }^{30}$. El testimonio de Dión avala la afirmación de que Demócrito fue uno de los más antiguos intérpretes de Homero y que su comentario gozó de gran prestigio pasando a formar parte de las enseñanzas escolares.

La crítica antigua y algunos estudios modernos han considerado a Demócrito como uno de los principales antecedentes de los estudios gramaticales y filológicos ${ }^{31}$. No obstante, si analizamos contextualmente los breves fragmentos que nos han llegado a través de Eustacio de Tesalónica ${ }^{32}$, comprobaremos que se trata de formas alegorizantes de exégesis física ${ }^{33}$ y mora ${ }^{34}$. La crítica moderna con mayor o menor acierto ha distribuido estos

29 Strom. VI 168 (= DK 68, B, 18), en el cual recoge la misma doctrina que Cicerón y

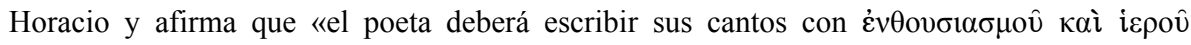
$\pi v \varepsilon v ́ \mu \alpha \tau o{ }^{\prime} »$. Esta doctrina de Demócrito, como se infiere de todos estos testimonios, había llegado a ser un tópico en la tradición doxográfica y enseñanza escolar.

30 El dato aparece recogido en Demócrito fr. B 21 DK. La existencia del tratado Sobre Homero está bien atestiguada. Cf. fr. DK 68 B 20-25. El título completo de la obra lo leemos en Diógenes Laercio, que atribuyó a Demócrito noventa obras en su Catálogo, resultado de los estudios de la filología alejandrina. Pero no todas eran auténticas.

31 Si realmente Demócrito hubiera escrito obras tales como Sobre las letras sagradas de Babilonia, Sobre las letras sagradas de Méroe, Sobre la historia, Doctrina caldea y frigia, podría ser considerado como uno de los mejores filólogos y gramáticos griegos del siglo $\mathrm{V}$. Pero ya la crítica antigua colocaba aparte estos escritos, por considerarlos espúreos.

32 Si las opiniones que las Digresiones del arzobispo Eustacio atribuyen a Demócrito son efectivamente suyas, sería necesario concluir que Demócrito interpretaba los personajes homéricos en sentido de alegoría física o moral.

33 Eustath. Schol. ad Od. XII 72: «Otros entienden el sol como Zeus ..., y dicen que los vapores húmedos, con que se alimenta el sol son la ambrosía, según opina también Demócrito». Sin embargo, resulta difícil convencerse de que $\dot{\alpha} \tau \mu$ í $\alpha \varsigma$ pertenezca al vocabulario del siglo V. El sentido del fragmento está mucho más en consonancia con la interpretación alegórica de la exégesis física del estoicismo tardío, en el que es habitual considerar al sol como Zeus.

34 Eustath. Schol. ad Od. XVI 376: «Hay que saber que en tanta consideración fue digno de mención este benévolo esclavo Eumeo entre los antiguos, que incluso averiguaron quién era su madre, Demócrito dijo que era Pobreza, Euforión, Pantea y Filóxeno de Sidón, Dánae». En cuanto a la atribución que se hace a Demócrito de interpretar a Pobreza como madre de Eumeo es posible, aunque una vez más la referencia tardía de Eustacio se inscribe en una tradición doxográfica y escolar.

EMERITA. Revista de Lingüística y Filología Clásica (EM) - LXV 2, 1997, pp. 195-220 
fragmentos en títulos como los siguientes: Sobre el ritmo y armonía, Sobre la poesía, Sobre las letras eufónicas y disonas, Sobre las palabras y Sobre Homero o de la ortoépeia y las glosas.

Las enseñanzas del $\pi \varepsilon \rho \grave{\imath} \gamma \rho \alpha \mu \mu \alpha ́ \tau \omega v$ nos hacen pensar en aquellas doctrinas que leemos en el Cratilo de Platón ${ }^{35}$. Parece que Platón se inspiró en concepciones expuestas con anterioridad por su rival, cuyo nombre oculta celosamente. En todo caso, estos testimonios tardíos del tratado $\pi \varepsilon \rho \grave{\imath}$ $\gamma \rho \alpha \mu \mu \alpha ́ \tau \omega v$ corroboran, al igual que los títulos de obras hoy perdidas, que el Abderita participó activamente en las reflexiones de su tiempo sobre temas lingüísticos, dedicando especial atención a la eufonía y disonía de las vocales y consonantes.

Otros fragmentos encasillados en estas obras «filológicas» responden a la hermenéutica de la literatura de tendencia cínico-estoica, que se desarrolla desde el siglo I después de Cristo. Así, por ejemplo, en la segunda parte del Euboico de Dión de Prusa, se hace un elogio de Pobreza, haciendo exégesis moral de muy diversos textos de Homero, de Eurípides y de otros poetas ${ }^{36}$. En esta literatura tardía los arquetipos de virtud, como veremos luego, suelen ser a veces obscuros e innominados personajes de los poemas homéricos, a los que para darles nobleza se les hace descendientes de virtudes morales personificadas $^{37}$. Por todo ello, la invención de la madre de Eumeo como prototipo de Pobreza más bien parece una creación tardía, cuya invención se atribuyó a Demócrito, por mera técnica escolar de acreditar opiniones con nombres de autorizados y famosos escritores antiguos.

De la lectura de los textos filológicos de Demócrito que nos han llegado $^{38}$, ubicados en la hipotética obra Sobre Homero, se infiere que, efectivamente, el autor de tales fragmentos está glosando el texto del poeta, pero el contenido parece haber sido reelaborado de acuerdo con la técnica de los escoliastas y de la tradición filológica. En el estado actual del texto, es imposible determinar el verdadero carácter formal de las glosas de Demócrito sobre el texto de Homero. Es doctrina común, sin embargo, en el

35 Tal vez la intervención de Hermógenes en Cratilo, 383 a y 384 b, refleja el pensamiento de Demócrito.

36 D. Chr. VII 82, ss.

37 El procedimiento, no obstante, aparece ya en Platón. Smp. 203 b.

38 Frs. B 22-25 DK.

EMERITA. Revista de Lingüística y Filología Clásica (EM) - LXV 2, 1997, pp. 195-220 
ámbito de la historia de los textos que estas atribuciones tardías se inspiran en una tradición doxográfica anterior, probablemente de época helenística, a cuyo núcleo fundamental remontan las elucubraciones de los escoliastas. Y, por lo tanto, muy probablemente no estamos leyendo textos del filósofo del siglo $\mathrm{V}$, sino de la tradición posterior.

Si fuera verdad, como dice la tradición, que Demócrito hizo exégesis del texto de Homero, habría que conjeturar que dicha exégesis se basaba ya en colecciones de palabras épicas anticuadas e inusitadas a las que ya en su tiempo se llamaba $\gamma \lambda \hat{\omega} \sigma \sigma \alpha$. Es, además muy verosímil que, en sus explicaciones, recurriera al uso de etimologías de nombres propios y de palabras raras del texto homérico y cabe pensar que algunas de ellas suscitaran el interés de los glosógrafos posteriores ${ }^{39}$, y de la tradición doxográfica. Ahora bien muy poco o casi nada conocemos de la hermenéutica de Demócrito al texto de Homero y del supuesto comentario prefilológico. Con los datos existentes, resulta muy problemático decidir cuestiones de autenticidad y las citas de Eustacio y de otros bizantinos per se no acreditan la autoría de Demócrito, aunque se mencione su nombre.

\section{Raigambre aristotélica de la gramática filológica y de la crítica literaria.}

Dión de Prusa ha comenzado su exposición sobre los intérpretes de Homero, por aquellos filósofos, cuyos estudios dieron lugar a la crítica literaria y luego a la Gramática: Demócrito, Aristóteles, Heraclides de Ponto, Aristarco de Samotracia ${ }^{40}$, Crates de Malos. A continuación del texto referente a Demócrito, nos dice:

También muchos otros han escrito sobre Homero, los unos alabando expresamente al poeta y, al mismo tiempo, esclareciendo algunos de los argumentos expuestos por él. Otros, por idéntica razón, han hecho exégesis de su pensamiento, no sólo Aristarco y Crates, sino también muchos otros de los que últimamente han sido llamados gramáticos y, anteriormente, críticos. También el mismo Aristóteles, de quien dicen que deriva la crítica y la gramática, trata del poeta en muchos de sus diálogos,

39 P. Pffeifer, Historia de la Filología Clásica, I, Gredos, Madrid, 1981, s. v. «Glosas», admite la posibilidad de que los rapsodos usaran colecciones de $\gamma \lambda \hat{\omega} \sigma \sigma \alpha$, esto es, palabras épicas inusitadas. Aristófanes atestigua este hecho en una de sus comedias perdidas, cf. K. Latte, «Glossographi», Philologus 80, 1925, pp. 147, ss.

40 Fundador de la escuela de Alejandría hacia el 150 a C.

EMERITA. Revista de Lingüística y Filología Clásica (EM) - LXV 2, 1997, pp. 195-220 
admirándolo en general y honrándolo, y todavía más Heraclides de Ponto ${ }^{41}$.

Dión, al encabezar su texto con los gramáticos o filólogos de la escuela alejandrina y los críticos de la escuela de Pérgamo, representadas una y otra por los dos maestros más significativos: Aristarco y Crates, parece sugerir que las mejores interpretaciones del texto de Homero se hallan entre ellos. Gramática y crítica literaria son dos actividades claramente diferenciadas. Sin embargo, «los que últimamente fueron llamados gramáticos, anteriormente habían sido conocidos como críticos», y a renglón seguido corrobora con un «dicen» que «el origen de la crítica literaria y de la gramática deriva del mismo Aristóteles» ${ }^{42} 43$, lo cual nos parece bastante convincente en lo que se refiere a la gramática filológica de los alejandrinos.

Conocemos otros muchos estudios en los que se defiende el origen de la gramática a partir del estoicismo. Pero este planteamiento referido a la filología es un error, y tratar aquí del problema excedería los límites de esta exposición. Cosa bien diferente es la realidad de que el título o epígrafe del manual de Dionisio de Tracia haya sido modificado en la tradición manuscrita, desde muy antiguo, para someter la gramática y la actividad filológica a la lógica y a la hermenéutica estoicas y de otro tipo, calificándola como $\tau \varepsilon ́ \chi \vee \eta$ y lo mismo podría afirmarse de la glosa ${ }^{43}$ que apare

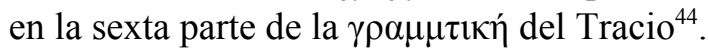

La filología helenística de la que Dión habla en este pasaje era herencia de muchos procedimientos antiguos, como el de los glosógrafos del siglo $\mathrm{V}$. El carácter escolar e instrumental aleja a la filología de los grandes debates teóricos. El aprendizaje de los poemas de Homero con técnicas de exégesis gramatical constituía la tarea principal de los jóvenes en las escuelas griegas y a esta actividad escolar remonta el núcleo fundamental de algunos corpus de scholia o de Lexica que han llegado hasta nosotros en sucesivas reelaboraciones ${ }^{45}$.

${ }^{41}$ D. Chr. LIII $1 \mathrm{~b}$

42 D. Chr. LIII 1.

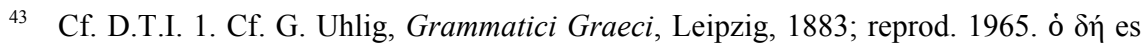
una formula habitual en la introducción de glosas, al igual que $\tau \hat{\omega} v \vee \dot{\varepsilon} v \tau \hat{n}$.

44 De estos problemas nos ocupamos en un estudio actualmente en prensa titulado: «El Concepto de Filología en Dionisio de Tracia».

45 G. Morocho Gayo, Scholia in Aeschyli Septem adversus Thebas, Universidad de EMERITA. Revista de Lingüística y Filología Clásica (EM) - LXV 2, 1997, pp. 195-220 
Era, pues, esta exégesis filológica una forma de racionalización del lenguaje, en la cual la lengua está concebida como una $\dot{\varepsilon} \mu \pi \varepsilon \rho^{\prime} \alpha$, estudiando en un plano descriptivo los fenómenos lingüísticos, los de la lengua hablada, pero principalmente los de la lengua escrita y literaria. Incluso algunos teóricos antiguos llevaban tan lejos la consideración «empírica» y la enseñanza de la lengua como oficio de artesano, que Sexto Empírico, en su tratado Contra los gramáticos, niega competencia a los filólogos para ir más allá del nivel puramente técnico de enseñar a hablar y escribir correctamente una lengua.

Modernamente se ha planteado la posibilidad de que Aristóteles llevara a cabo una recensión de la Ilíada ${ }^{46}$. En mi opinión resulta difícil admitir la existencia de una recensión en época tan temprana, aunque tal recensión no fuera similar a las posteriores «ediciones» de los gramáticos alejandrinos. Sin embargo, sí parece evidente que Aristóteles hiciera numerosas correcciones en el texto homérico, anticipándose a lo que después será la filología helenística. También Dión hace a Aristóteles padre de la crítica literaria, el cual en obras como Dificultades homéricas, Sobre los poetas, y en la Poética, así como en otros diálogos «despliega su saber acerca de Homero, elogiándolo y honrándolo la mayor parte de las veces». En todas estas obras Aristóteles trataba difíciles problemas de crítica literaria, «y eso lo hace todavía más Heraclides el de Ponto ${ }^{47}$. El Prusense nos ofrece, por lo tanto, un testimonio importante sobre la evolución y desarrollo de la filología a partir de la escuela peripatética.

Dión en este pasaje, por ser ajeno a sus fines, silencia el vivo debate sobre el concepto mismo de gramática, que tenia lugar entre los teóricos de su generación, filósofos y gramáticos, y que había comenzado en la primera mitad del siglo I a. C. De la misma manera oculta las polémicas entre los gramáticos de la escuela de Alejandría y los críticos de la escuela de Pérgamo. En Dión nos hallamos ante un fenómeno de sincretismo, que trata

León, 1989, pp. *12-*17

46 M. Sanz Morales, «Sobre la existencia de una recensión de la Ilíada debida a Aristóteles», Minerva 5, 1991, pp. 57-80.

47 H. Lamar Crosby, Dio Chrysostomos, Londres 1972, p. 357, n 5. Este Heraclides Ponticus parece que es el discípulo de Platón y Aristóteles. De él habla Diógenes Laercio, V 86-88. No creo que Dión se refiera a Heraclides Póntico, llamado el Joven, gramático nacido en Heraclea Póntica y discípulo de Dídimo, que vivió en tiempos de Claudio y Nerón.

EMERITA. Revista de Lingüística y Filología Clásica (EM) - LXV 2, 1997, pp. 195-220 
de limar todas las diferencias de la tradición helénica y de conciliarlas entre sí.

\section{El debate sobre la definición de gramática filológica.}

En Platón y Aristóteles la $\tau \varepsilon \dot{\chi} \chi \eta \eta ~ \gamma \rho \alpha \mu \mu \alpha \tau$

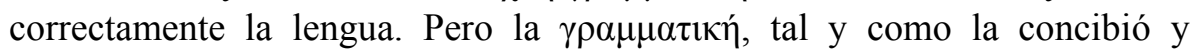
dividió en partes Dionisio de Tracia era el resultado de la técnica de

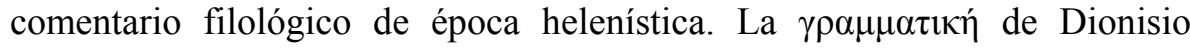
hemos de situarla dentro de la tradición de la filología alejandrina. La tradición hace a Dionisio un discípulo de Aristarco, en quien Dión ejemplifica la interpretación filológica de la escuela de Alejandría. Los escolios de Homero nos han transmitido noticias sobre el quehacer filológico de los primeros filólogos helenísticos, herederos de la tradición anterior, principalmente de la emanada de Aristóteles y de su escuela peripatética ${ }^{48}$.

Los filólogos de Alejandría desde el siglo III hasta comienzos del siglo II a. C. llegaron a fijar un riguroso trabajo científico, que Dionisio de Tracia va

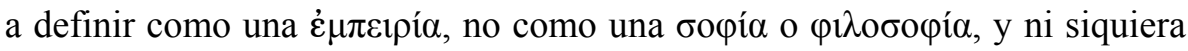
como una $\dot{\varepsilon} \pi \iota \tau \eta \dot{\mu} \mu \eta$, ni como una $\tau \dot{\varepsilon} \chi v \eta$. La $\dot{\varepsilon} \mu \pi \varepsilon \iota p^{\prime} \alpha$ excluye per se los métodos abstractos y especulativos. La filología helenística no implicaba una «teoría del conocimiento» a partir de un modelo matemático como el de Platón ${ }^{49}$, o biológico como el de Aristóteles, ni tenía en cuenta una determinada creencia religiosa. La actividad filológica era un saber práctico.

El problema de la definición de gramática filológica no parece tener solución satisfactoria desde un determinado planteamiento filosófico. Si a la gramática se la define como $\dot{\varepsilon} \mu \pi \varepsilon \imath \rho i ́ \alpha$, y se la hace independiente de cualquier sistema filosófico, entonces es «como una ramera puesta en cualquier esquina, dispuesta a marcharse con el primero que llega $»^{50}$. Pero si

48 Un buen estudio descriptivo sobre el comentario en época helenística en Marina del Fabro, «Il commentario nella tradizione papiracea», Studia Papirologica 18, 1979, pp. 69-132.

49 Como es bien sabido Platón se sirve de tres alegorías: la de la luz (P1 R. 507 a-509 c), la de la línea (P1 R. 509 d-511 e) y la de la caverna.(P1 $R .514$ a-517 c) El enorme salto entre el plano de lo visible y el plano de lo inteligible se hace sobre la base del principio de la analogía matemática.

50 La traducción no es literal. El texto griego de S. E. Adu. Gram. I 61 es más obsceno EMERITA. Revista de Lingüística y Filología Clásica (EM) - LXV 2, 1997, pp. 195-220 
se celebran las bodas de Filología con Mercurio, entonces Filología llega a ser una criada, al servicio de un sistema de lógica o de teología ${ }^{51}$.

La definición filológica que Dionisio de Tracia, discípulo de Aristarco, había dado a su gramática filológica, no complacía en modo alguno a los diversos sistemas de hermenéutica y de crítica literaria. Una definición de

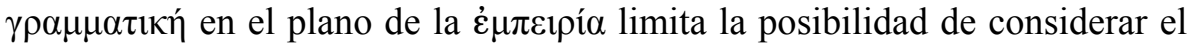
estudio de la lengua como elemento puramente ancilar de una hermenéutica, llevada a cabo desde unos presupuestos especulativos y filosóficos. Todos los dardos de los gramáticos y filósofos, ya desde el siglo I a C., se van a

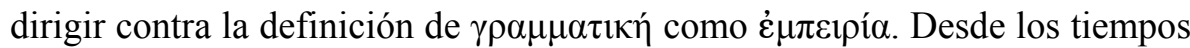
de Dionisio de Tracia hasta los de Sexto Empírico ${ }^{52}$ asistimos a un acalorado

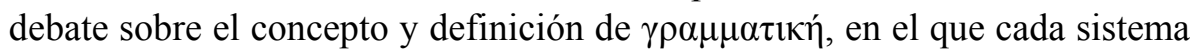
de filosofía intenta definir la $\gamma \rho \alpha \mu \mu \alpha \tau$ cń de conformidad con su lógica y metafísica. Evidentemente muchos gramáticos, participaban de la verdad de un sistema filosófico y, en consonancia con ellos, van a definir la

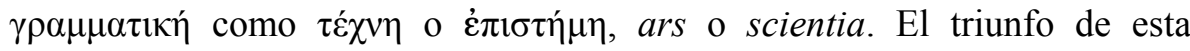

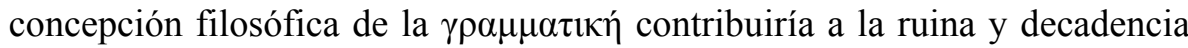
de los estudios específicamente filológicos.

La $\gamma \rho \alpha \mu \mu \alpha \tau \iota \kappa$, dice Sexto Empírico, es el punto de arranque de todas las demás disciplinas, un prerrequisito para el estudio de las demás ciencias, o

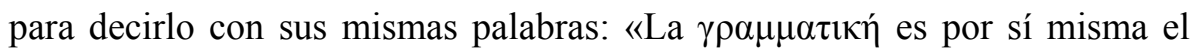
pórtico o prerrequisito en relación con las enseñanzas de las demás ciencias».

Entre los oponentes de Dionisio de Tracia, Sexto Empírico cita en primer

por estar inserto en la mejor tradición erótica de las heteras de la lírica y de la comedia grie-

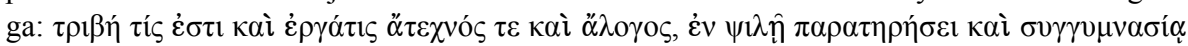
$\kappa \varepsilon \mu \varepsilon \dot{v \eta}$. Este tratado evítanlo citar y estudiar, como si de una sierpe se tratara, los partidarios cada vez más numerosos de una gramática neo-lógica. Y sin embargo, encierra los secretos del debate gramatical de tres siglos. Sin un conocimiento muy a fondo del mismo resulta vanidad publicar libros o artículos sobre los problemas de la teoría gramatical de la Antigüedad.

51 De hecho la Inquisición española en el siglo XVI, advirtió muy pronto los peligros de una praxis filológica, independiente de la hermenéutica, practicada por humanistas como Nebrija. Éste, en los primeros años de siglo XVI, tuvo que escribir su Apología, en defensa de la gramática filológica. Cf. nuestra exposición: «La Filología Bíblica del Humanismo renacentista: Continuidad y ruptura». (En prensa).

52 La razón de este debate nos la ofrece el mismo S. E. Adu. Gram. I 41 y ss.

EMERITA. Revista de Lingüística y Filología Clásica (EM) - LXV 2, 1997, pp. 195-220 
lugar a Ptolomeo el peripatético ${ }^{53}$, el cual había reprochado a Dionisio de

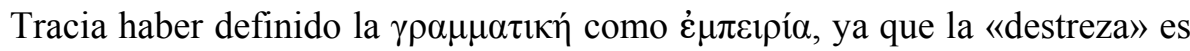
una clase de práctica y de tarea sin arte y $\sin \lambda$ ó ${ }^{\circ} \varsigma$ o razonamiento que no sabe explicar las causas, por consistir en la mera observación y ejercicio,

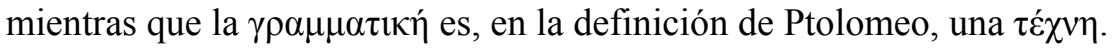

Sin embargo, prosigue Sexto Empírico, Ptolomeo se equivoca al no

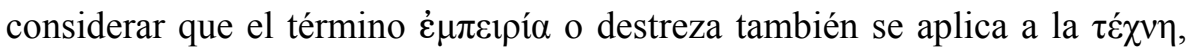
pues designamos indistintamente a los mismos hombres como expertos o artistas y, por ello, Metrodoro el epicúreo ${ }^{54}$ dijo que la filosofía es la única $\dot{\varepsilon} \mu \pi \varepsilon p_{i} \alpha$ en los asuntos de que se ocupa, porque mira su propio fín, queriendo significar que es el único arte ya que, preferentemente, se ocupa de ordenar el conocimiento en muchos y muy variados asuntos, de igual manera que llamamos expertos en la vida a los ancianos, porque han visto y aprendido muchas cosas.

A juzgar por estas palabras resulta evidente que tanto Ptolomeo como

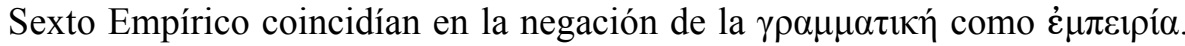
Si Dionisio de Tracia hubiera rotulado o definido como $\tau \dot{\varepsilon} \chi v \eta$ su manual, carecerían de todo sentido las objecciones de los gramáticos del siglo I y del filósofo del siglo II, por lo que es necesario concluir que tanto el epígrafe TEXNH de la tradición manuscrita, como la segunda glosa de la sexta parte: $\tau \hat{\omega} v \dot{\varepsilon} v \tau \hat{\eta} \iota \tau \dot{\chi} \chi v \eta$, son un añadido de la tradición.

Otro de los oponentes de Dionisio fue Asclepíades de Mirlea, que vivió en el siglo I a. C. Asclepíades inició una nueva dirección en los estudios gramaticales. Tanto él como sus seguidores reprochan al de Tracia haber

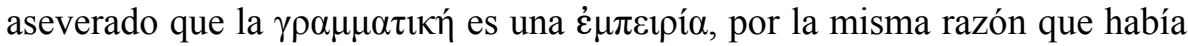
expuesto Ptolomeo, cuando reprochaba al Tracio haber declarado que era $\dot{\varepsilon} \mu \pi \varepsilon \imath \rho_{i ́ \alpha} \alpha$ «en su mayor parte» ${ }^{55}$.

Sexto Empírico distingue claramente dos concepciones de gramática ${ }^{56}$. La

53 Probablemente se trata de Tolomeo Pindarión, contemporáneo de Dionisio de Tracia,

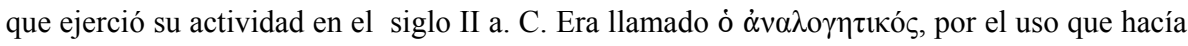
de la analogía.

54 Evidentemente, el materialismo de Metrodoro estaba en consonancia con el escepticismo del Empírico.

55 S. E. Adu. Gram. I 72.

56 S. E. Adu. Gram. I 41-52.

EMERITA. Revista de Lingüística y Filología Clásica (EM) - LXV 2, 1997, pp. 195-220 
una se ocupa solamente de «los elementos y sus combinaciones y es el arte

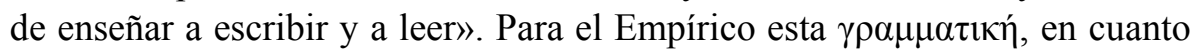
permite luchar contra el olvido y es el mejor recurso para la transmisión de los conocimientos, es una de las artes más útiles. La segunda gramática es más profunda y se ocupa de cuestiones como «la invención y la naturaleza de los elementos, la clasificación de las palabras en las partes de la oración, etc» ... Esta gramática es rechazada por Sexto Empírico por ser «demasiado pretenciosa y demasiado curiosa ${ }^{57}$.

El Empírico, pues, distingue, de acuerdo con la tradición de su tiempo,

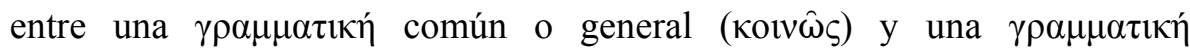

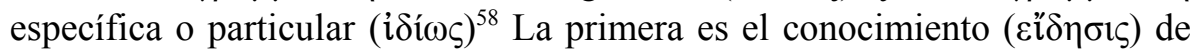

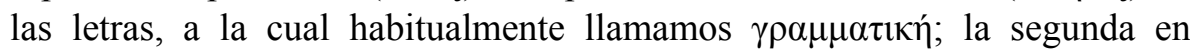
sentido propio o específico es «la perfecta», $\dot{\eta} \dot{\varepsilon} v \tau \varepsilon \lambda \eta ́ s$. Sexto Empírico, al utilizar el sustantivo $\varepsilon \succsim \delta \eta \sigma ı \varsigma$, está tomando un claro partido acorde con su planteamiento filosófico dentro del debate lingüístico, por eso afirma que la

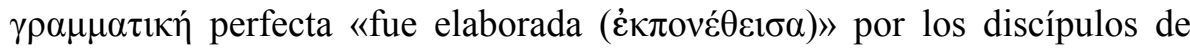
Crates de Malos en Cilicia, fundador de la escuela de Pérgamo como opuesta a la de Alejandría, representada por Aristófanes de Bizancio y Aristarco. Nos parece significativo que Sexto Empírico cite en primer lugar a Crates y a la

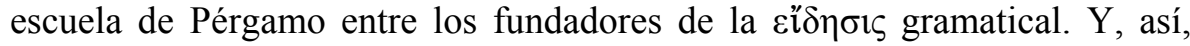

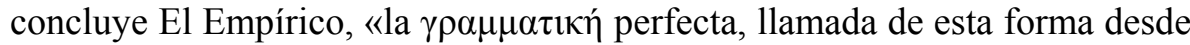
el principio por el conocimiento de las letras, amplió también sus conocimientos con los más variados recursos y teorías técnicas sobre ellas».

\section{Formas de hermenéutica enumeradas por Dión de Prusa.}

Entre los filósofos, cita Dión en primer lugar a Platón ${ }^{59}$, que menciona a Homero en todas las partes de su obra, y siente admiración por el encanto y deleite que le producen los versos del poeta; sin embargo, lo censura muchas veces por lo que dice en sus mitos y en sus discursos acerca de los dioses, en la idea de que su lectura no era cosa conveniente para los hombres y mujeres

57 S. E, Adu. Gram. I 54-98, 153, 269. Cf. J. Lallot, La grammaire de Denys le Thrace, París, 1989, p. 71.

58 S. E, Adu. Gram. I 44.

59 D. Chr. LIII 2. Cf. Pl. R. 378 b-e; 398 a; 607 a.

EMERITA. Revista de Lingüística y Filología Clásica (EM) - LXV 2, 1997, pp. 195-220 
de la república ideal ${ }^{60}$.

Tampoco enumera Dión los sistemas de hermenéutica racionalista, ni alude a autores como Jenófanes de Colofón, quien afirmaban que Homero estaba errado al transmitir a los hombres, por medio de mitos, la imagen de la divinidad. Tampoco se refiere a la hermenéutica racionalista de los sofistas. En cambio, al exponer el rechazo que hace Platón de la hermenéutica alegórica de su tiempo ${ }^{61}$, siguiendo la técnica alusiva, Dión sugiere queconoce la técnica de la úđóvola de Teágenes de Regio y de todos aquellos que en defensa de Homero sostenían que en las palabras del poeta existía «un sentido subyacente».

Grandes creaciones literarias de la Antigüedad clásica, como las de Píndaro, Esquilo o Sófocles adoptaron los principios propios de la u̇ióvora de su tiempo y dieron nueva vida religiosa y literaria a los personajes del viejo mito, unas veces identificando a los dioses con fuerzas y fenónemos de la naturaleza y otras personificándolos con virtudes y vicios. Esta

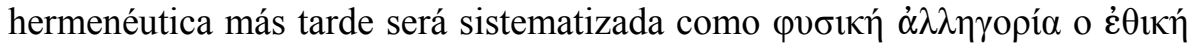
$\dot{\alpha} \lambda \lambda \eta \gamma о \rho^{\prime} \alpha^{62}$.

Y otro tanto hicieron diversas religiones, como el orfismo, con su recurso a la etimología filosófica y a su peculiar forma de exégesis, para explicar los nombres divinos y las verdades de su concepción religiosa sobre el mundo y la vida humana.

También en la literatura de los filósofos, sofistas y oradores del siglo V, e incluso en grandes genios literarios como Gorgias o Eurípides, los viejos mitos, como el de Helena, se transforman y son portadores de nuevas ficciones al servicio del racionalismo e ilustración griega. La arqueología de Tucídides $^{63}$ es ya un ensayo magistral de exégesis histórica, que culminará en sistemas como el de Evémero de Paros o el de Paléfato, los cuales

60 Sobre hermenéutica platónica en relación con el mito nos hemos ocupado en otro lugar: «Hermenéutica y alegoría del Mito en Platón» (En prensa).

61 D. Chr. LIII 3. Cf. Pl. R. 386 a-387 c.

62 R. Pfeiffer, Historia de la Filología Clásica, Madrid, 1981, p. 37; J. Perret, «Allégorie, hyponoíai, inspiration. Sur les exégèses anciennes d' Homére», Cahiers des Études Anciennes 14, 1982, pp. 65-73.

63 Th. I 2-19 Tucídides hace una interpretación de «exégesis histórica» de los elementos legendarios que narraban los orígenes de la historia griega.

EMERITA. Revista de Lingüística y Filología Clásica (EM) - LXV 2, 1997, pp. 195-220 
reducen los mitos a narraciones o personajes de tipo histórico o a fenómenos geográficos, para no hablar de interpretaciones astrales como la de Eratóstenes. Posiblemente como reacción a esta exégesis racionalista se creará toda una interpretación en la que sitúa la realidad de los dioses y los héroes en las constelaciones celestes ${ }^{64}$.

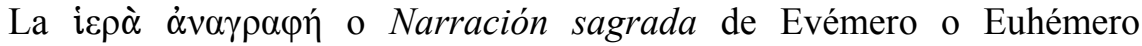
(311-298 a. C) combina una descripción de islas imaginarias situadas al Este del mundo griego, sirviéndose de un viaje imaginario por aguas del Indico, con una teoría del origen de los dioses, enseñando que Urano, Crono y Zeus habían sido grandes reyes en un momento histórico, elevados posteriormente a la categoría de dioses por el favor del pueblo ${ }^{65}$. Por último, un esbozo de sociedad utópica, con otros elementos amalgamados era el argumento principal en las Filípicas de Teopompo ${ }^{66}$. La utopía de Evémero situaba a dioses y hombres, siguiendo la tradición de la épica y lírica griegas, en una línea cuya frontera estaba muy borrosa. El evemerismo, pues, al suponer que algunos dioses habían sido originalmente héroes, se alineaba con el racionalismo de la historiografía jonia. Es notorio que esta interpretación alcanzó gran difusión gracias a autores como Diodoro Sículo ${ }^{67}$, que nos ha conservado varios fragmentos de Evémero en el Libro VI, al igual que el escritor cristiano Lactancio ${ }^{68}$.

\section{La hermenéutica del cinismo-estoicismo.}

Por último, Dión concluye su breve historia de las interpretaciones exegéticas de Homero con la hermenéutica que, según él, comenzó en

64 A. Olivieri, Pseudo-Eratosthenis Catasterismi en Mythographi graeci, fasc. I, vol. III, Leipzig, 1897; cf. trad. esp. de J. R. del Canto Nieto, Eratóstenes. Catasterismos, Ediciones Clásicas, Madrid, 1992; A. Breysig, Germanici Caesaris Aratea, Leipzig, 1898; E. Mass, Commentariorum in Aratum Reliquiae, Berlin, 1953; V. Martin, Aratus latinus cum scholiis, Florencia, 1956; A. Le Boeuffle, Hygini de astronomia, Paris 1983; F. Solmsen, «Eratosthenes as Platonist and Poet», TAPhA 73, 1942, pp. 192, ss; E. J. Webb, Los nombres de las estrellas, México, 1982. Esteban Calderón Dorda, Arato. Fenómenos.- Gémino, Introducción a los fenómenos. Madrid, 1993.

65 Jacoby, $F G r H 63$.

66 Jacoby, FGrH 115 F 75.

${ }^{67}$ J. Lens Tuero, «Sobre la naturaleza de la Biblioteca Histórica de Diodoro Sículo», Estudios de Filología Griega 2, 1986, pp. 9-43.

68 H. F. van der Meer, Euhemerus of Messene, diss. Amsterdam 1948.

EMERITA. Revista de Lingüística y Filología Clásica (EM) - LXV 2, 1997, pp. 195-220 
Antístenes y los cínicos ${ }^{69}$, y prosiguió Zenón y los estoicos ${ }^{70}$. Simplificando tendencias y borrando límites cronológicos, Dión atribuyó a Antístenes y a Zenón, la invención y práctica de los dos procedimientos más generalizados de la exégesis de su tiempo. Formas de exégesis que empleaban los autores más representativos del cinismo-estoicismo de los siglos I-II p. C. y, sobre todo, el propio Dión. Éste suele hacer una exégesis $\kappa \alpha \tau \grave{\alpha} \delta o ́ \xi \alpha v$ y una exégesis $\kappa \alpha \tau^{\prime} \dot{\alpha} \lambda \hat{\eta} \theta \varepsilon 1 \alpha \nu^{71}$.

Dión afirma que fue Antístenes ${ }^{72}$ el primero en formular estos dos principios de hermenéutica, que él mismo suele emplear a lo largo de sus ochenta ensayos o Discursos. Homero habría dicho cosas $\kappa \alpha \tau \grave{\alpha} \delta$ ó $\xi \alpha v$, cuando se expresaba según la opinión del vulgo y, por lo tanto, en estos casos, habría mentido. La inspiración de la musa le habría dictado no la verdad, sino el engaño. En esta exégesis $\kappa \alpha \tau \grave{\alpha} \delta o ́ \xi \alpha v$ se atacaba a Homero con los mismos argumentos de la hermenéutica racionalista o historicista.

Sin embargo, estos ataques llegan a ser en la realidad literaria de la segunda sofística como un lusus literario o retórico, porque en el fondo se está defendiendo al poeta y a la religión tradicional de la Hélade. Resulta evidente que muchos relatos y mitos de Homero atacaban postulados elementales de la ética humana. En estos casos el intérprete busca en sentidos subyacentes el verdadero mensaje de las musas mediante el recurso a una exégesis alegórica, física, moral o de otro tipo.

Este mismo procedimiento hermenéutico lo practica Filón en los libros

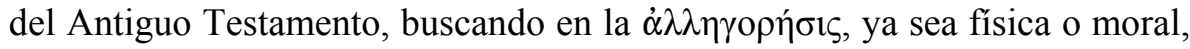
$\mathrm{o}$ en determinados arquetipos del A. T. el significado profundamente religioso de muchos relatos bíblicos, vertiendo y traduciendo el pensamiento judío tradicional en moldes de cultura griega, accesible a los hombres de su tiempo, imbuidos del llamado judaísmo helenístico, recurso que seguirán después muchos exegetas del cristianismo ${ }^{73}$.

69 D. Chr. LIII 5 b.

70 D. Chr. LIII 5 a.

71 L. Gil, art. cit. 1980, pp. 43-78.

72 Antístenes es uno de los pincipales arquetipos de Dión en los Discursos de tendencia cínica. Cf. D. Chr. VIII 1-2, 4.

73 Sobre la exégesis alegórica de Filón, cf. J. Cazeaux, «Philon d' Alexandrie, exégète», $A N R W$ II, 21, 1984, pp. 156-226; B. L. Mack, «Philo Judaeus and Exegetical Traditions in

EMERITA. Revista de Lingüística y Filología Clásica (EM) - LXV 2, 1997, pp. 195-220 
Otras veces, por el contrario, el poeta habría hablado $\kappa \alpha \tau^{\prime} \dot{\alpha} \lambda \dot{\eta} \theta \varepsilon 1 \alpha v$, es decir, los versos de Homero han de ser interpretados en el nivel de

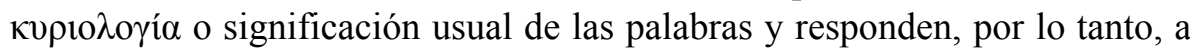
la verdad de las cosas tal y como son en la realidad. Dión ejemplifica esta forma de exégesis $\kappa \alpha \tau^{\prime} \dot{\alpha} \lambda \dot{\eta} \theta \varepsilon 1 \alpha \nu$, cuando pinta el retrato del buen príncipe, fijándose en la alegoría del buen pastor $^{74}$, o bien cuando elabora meras $\pi \alpha \rho \alpha \varphi \rho \alpha ́ \sigma \varepsilon ı \varsigma$ Homero:

«El rey es imagen de Zeus, porque sólo Zeus es nombrado rey y padre de los dioses y de los hombres, protector de ciudades, señor de los amigos y camaradas, guardián de linajes, y además de esto valedor de suplicantes, Dios de amparo, y defensor de fugitivos y protector de la hospitalidad. Así lo llama Homero y con otros atributos, todos ellos buenos y portadores de bondad», dice Dión ${ }^{75}$.

No comentaré aquí ninguno de los innumerables ejemplos que nos ofrecen los ensayos de Dión sobre exégesis física, ética o moral o bien histórica, en la línea del más puro racionalismo. De algunas de esta modalidades, nos ocupamos en nuestro comentario del Himno al sol del Boristénico $^{76}$. Pasajes de exégesis física muy significativos son, por ejemplo, cuando el Sofista explica la unión de Zeus con Hera, hierogamia que se interpreta como una eclosión de la primavera ${ }^{77}$, o los numerosos pasajes de exégesis moral, por ejemplo el mito de las sirenas ${ }^{78}$ o el de las serpientes de Libia $^{79}$, símbolos de los deleites carnales que hechizan al hombre, o bien cuando describe las peregrinaciones de Odiseo, arquetipo de los viajes del sabio cínico.

En la segunda parte del Euboico, por el contrario, encontramos un largo

Alexandria», ib., pp. 227-271; F. Trisoglio, «Filone Alessandrino e l' esegesi cristiana», ib., pp. 588-730.

74 I. Rodríguez, «Origen prehelénico de las imágenes ‘camino' y ‘pastor'», Helmantica 7, 1956, pp. 261-287.

75 D. Chr. I $38-41$.

76 Cf. nuestro comentario: «Exégesis de un mito oriental en Dión de Prusa: Or. XXXVI, 39-47», en J. A. López Férez (ed.) De Homero a Libanio. Estudios actuales sobre textos griegos. II, Madrid, 1995, pp. 345-364 y «Formas de exégesis y reinterpretación de Arquetipos en Dión de Prusa», Caesura 3, 1993, pp. 63-87

77 D. Chr. XI 21 La unión de Zeus con Hera en este pasaje significa la eclosión de la naturaleza.

78 D. Chr. VIII 21.

79 D. Chr. V.

EMERITA. Revista de Lingüística y Filología Clásica (EM) - LXV 2, 1997, pp. 195-220 
desarrollo de exégesis histórica ${ }^{80}$. En este excurso no faltan pasajes de cierta

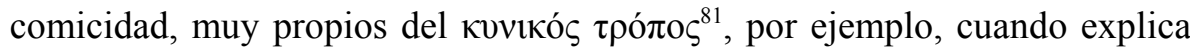
el comportamiento agradecido de algunos maridos cornudos, que invitan a las fiestas de cumpleaños al amante de su mujer, por considerarlo amigo de

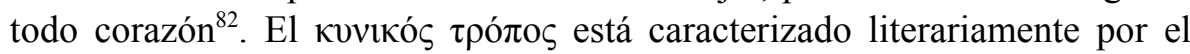

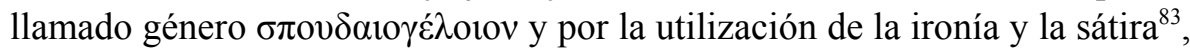
que son recursos que emplea habitualmente Dión en pasajes como en el que presenta la figura del gordo y el flaco en Diógenes o Discurso de la virtud. En este caso hay una crítica sin paliativos de los atletas profesionales y una invectiva contra los entrenadores de tales tales deportistas, médicos que obtenían pingües beneficios.

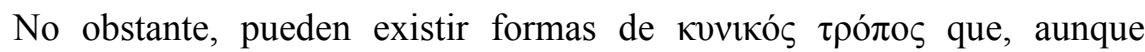
reciban este nombre, por utilizar tópicos literarios y formas que remontan a los fundadores del cinismo, nada o muy poco tienen que ver con el carácter específico del pensamiento cínico, ya que no existió como tal un sistema de pensamiento cínico. El denominado кvvikós ßíos es la forma de vida que caracteriza la actitud personal de los filósofos cínicos, cuyos arquetipos principales eran Heracles, Odiseo, Ayax, Sócrates, Antístenes, Diógenes y Crates $^{84}$.

Durante su destierro en tiempos de Diocleciano el Sofista de Prusa adoptó la forma característica del кvvikós Bíos, siendo esta una de las principales coordenadas para la interpretación correcta de algunos de sus ensayos. Los filósofos cínicos eran bien conocidos por sus formas externas: vida de

80 D. Chr. VII 8-152.

81 En la realidad histórica es muy difícil una delimitación rigurosa de la literatura de tendencia cínica, ya que esta corriente se negó a organizarse como escuela, existiendo únicamente lazos y relaciones, no siempre cordiales, entre maestro y discípulos. Hay que conside-

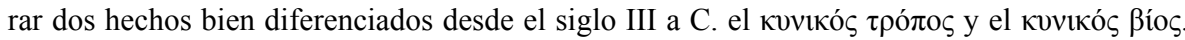

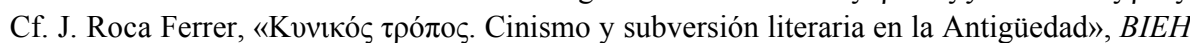
8-9, 1974-1975, pp. 1-227.

82 D. Chr. VII 141-142.

83 L. Giangrande, The Use of Spoudaiogeloion in Greek and Roman Literature, La Haye/Paris, 1972

${ }^{84}$ Cf. D. R. Dudley, A History of Cynism. From Diogenes to the VI th A. D. Londres 1937; reimpr. New YorK, 1974. J. M. André, «Les écoles philosophiques aux deux premiers siécles de l'Empire», ANRW 361, 1987, pp. 5-77.

EMERITA. Revista de Lingüística y Filología Clásica (EM) - LXV 2, 1997, pp. 195-220 
caminante o peregrinante, el fardo, la capa raída y el bastón. Sin embargo, existen enormes dificultades para delimitar los contenidos específicos del pensamiento cínico y de la exégesis que hacían de Homero y de los poetas. Conocemos bien solamente uno de los dos momentos de esplendor: el de los siglos I-II p. C., no así el primero, siglos IV-III a. C. Estos dos períodos fueron coincidentes con profundos cambios culturales y están caracterizados por la supresión de la libertad y el aumento de la burocracia ${ }^{85}$.

\section{Hermenéutica de tendencia cínica en Dión de Prusa.}

La técnica más característica de exégesis dionea aparece empleada en otros textos del cinismo contemporáneo o inmediatamente posterior. Así, por ejemplo en el Pap. Gen. 271, un brahmán de la India ${ }^{86}$, al igual que hace el sacerdote egipcio en el Troyano, arremete dialécticamente contra Homero, Hesíodo y los poetas de la Hélade, por haber pervertido la moralidad pública con el comportamiento de sus dioses y de sus héroes. El brahmán echa en cara al poeta el pedir a la musa que le refiera la cólera de Aquiles, ya que a los dioses no les importa nada cantar las emociones y pasiones de los hombres.

La sabiduría de este brahmán, como la del sacerdote egipcio en el Troyano, o la de los magos persas en el Boristénico en la ficción literaria

\footnotetext{
85 Cf. M.-O. Goulet-Cazé, «Le cynisme à l'époqe impériale», ANRW 36, 1990, pp. $2720-2633$

${ }^{86}$ Las siete últimas columnas de este papiro recogen el texto que ya nos era conocido por la Carta del Pseudo-Heráclito (cf. H. W. Attridge, «First-century cynism in the epistles of Heraclitus», HThS, XIX, 1976 y M. Cappelletti, Epistolas Pseudo heracliteas, Introd. Trad. y notas, Universidad Nacional del Litoral, Rosario, 1960) a la cual añade un desarrollo nuevo cf. V. Martin, «Un recueil des diatribes cyniques Pap. Gen. inv. 271», MH 16, 1959 y I. Diggle, «Pseudo-Heraclitus. Pap. Gen. inv. 271, XIV 40-42», ZPE 20, 1976, p. 299. En las ocho primeras columnas se recoge un diálogo entre Alejandro y Dándamis, el más sabio de los brahmanes de la India. En definitiva, el tema central lo constituye el tópico del encuentro del rey y el sabio, atestiguado ya en Heródoto en el diálogo de Solón y Creso y recogido y desarrollado en autores como Dión de Prusa en su Discurso IV de la Realeza. En este Discurso de Dión, Alejandro, el rey, se encuentra con Diógenes. El argumento del papiro lo constituye, pues, el agón o debate entre el sabio cínico representado por Dándamis y el rey, que como suele ser tradicional está encarnado en la figura de Alejandro Magno, cf. A. Nodar Domínguez, Papyrus Genevensis Inv. 271. Edición del texto. Traducción al español. Comentario. Memoria de licenciatura. Universidad de León, 1993.
}

EMERITA. Revista de Lingüística y Filología Clásica (EM) - LXV 2, 1997, pp. 195-220 
dionea, es muy superior a la de Homero. Sin embargo, esta es una técnica que en Dión se ha convertido en un procedimiento literario. La misma que sigue el anónimo autor de la columna XIV del Papiro Genevensis ${ }^{87}$. El contenido de esta columna y también de la siguiente, aunque desafortunadamente sólo pueden leerse las primeras letras, lo constituye un feroz ataque contra Alejandro, detrás del cual puede esconderse algún emperador romano de la dinastía julio-claudia, por haber levantado sus puñales contra padres, hijos, hermanos, amigos, contra el desierto, contra la multitud y contra los animales inocentes. Alejandro en este pasaje es antitipo del buen príncipe, ya que está lleno de injusticia, como el gordo en el Discurso dioneo Sobre la Virtud estaba lleno de gula, acidia y lujuria.

El autor del Papiro y el Sofista de Prusa establecen en su exégesis una representación figurada que conecta dos acontecimientos o personas, el primero de los cuales tiene significación por sí mismo y también para el segundo. Solamente el conocimiento de las dos personas o acontecimientos es un acto espiritual, y como tal no se agota en conceptos o abstracciones. Tal es el sentido profundo de la remodelación de los arquetipos en Dión de Prusa $^{88}$.

Esta forma de exégesis $\kappa \alpha \tau \grave{\alpha} \delta o ́ \xi \alpha \nu$ que versa no sobre un texto sino sobre un arquetipo, hay que situarla dentro del contexto literario del siglo II p. C. Los arquetipos aparecen dentro de una visión más global de un texto poético o literario, que se interpreta con unas coordenadas nuevas. El Sofista en el Discurso II de la Realeza condena, al igual que haría según conjeturamos en la parte deteriorada el autor del Papiro, la poesía de Arquíloco, Safo, Anacreonte y los líricos corales, salvando los relatos de la conquista de Troya que hacen Estesícoro y Píndaro. Pero en el Discurso II nos movemos en un plano de exégesis $\kappa \alpha \tau$ ' $\dot{\alpha} \lambda \dot{\eta} \theta \varepsilon 1 \alpha v$ por lo cual se considera la poesía de Homero como la única apta para la educación del Príncipe ideal.

La gran diferencia entre el Discurso II de la Realeza en que se elogia la poesía de Homero y el Troyano, en el cual se censura al poeta, radica, por lo

87 En esta columna XIV comienza un desarrollo nuevo siguiendo una técnica de composición especificamente exegética, la cual es un ejemplo, como el Troyano de Dión, de lo que venimos llamando exégesis $\kappa \alpha \tau \grave{\alpha} \delta o ́ \xi \alpha v$.

88 D. Chr. VIII 14.

EMERITA. Revista de Lingüística y Filología Clásica (EM) - LXV 2, 1997, pp. 195-220 
tanto, en que se siguen procedimientos de exégesis diferente. Esta diversidad de modalidades interpretativas, en los Discursos de Dión y en otros autores y obras de la segunda sofística, explica las aparentes contradicciones que puede ofrecer un mismo escritor y puede despistar a un lector inadvertido, cuando ignora que la hermenéutica era en la segunda sofística y mucho antes un recurso habitual de composición literaria. Consecuentemente en muchos escritores de esta época, procedimiento que será muy imitado, cuando de un mismo personaje arquetípico se ofrecen versiones distintas o contrapuestas es un hecho que generalmente responde al uso de diversas técnicas exegéticas.

El Troyano presenta buenos ejemplos de los procedimientos exegéticos más característicos de Dión. En este ensayo, sin embargo, predomina la exégesis $\kappa \alpha \tau \grave{\alpha} \delta o ́ \xi \alpha v$, ya que la mayor parte del discurso constituye un desarrollo de las tesis defendidas por la crítica racionalista en relación directa con la idea de la literatura y el arte como engaño y apariencia. Dión explica aquellos versos en los que el poeta está mintiendo, por ejemplo, cuando atribuye una lengua a los dioses y otra a los hombres ${ }^{89}$. El Sofista continuamente tacha a Homero de embustero. Sin embargo, el portavoz de la verdad en este discurso es un sacerdote egipcio, casta que en la tradición griega tenía fama de mentirosa y falaz. Quien está mintiendo es el sacerdote egipcio. La Helena de Estesícoro, Euríbides y Gorgias, como el Troyano de Dión, son obras en las que el personaje se mueve en un doble plano el de la

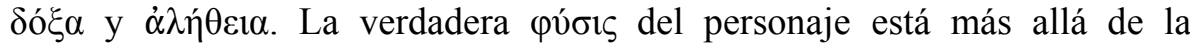
apariencia.

Este es un procedimiento literario muy sutil de la segunda sofística, porque en realidad todo el Discurso XI es una alabanza del poeta, como verdadero educador de la Hélade. El ensayo, en su conjunto, constituye un intento por esclarecer los límites entre verdad y engaño en la naturaleza de la ficción poética y recoge los resultados del debate ya antiguo entre la crítica racionalista, por un lado, y la versión, por otra parte, que acerca del acontecimiento y personajes de la guerra de Troya había ofrecido la llamada $\dot{\alpha} \lambda \lambda \varepsilon \gamma o \rho \eta ́ \sigma ı \varsigma$ practicada por los defensores de Homero. Dión realza la antítesis entre verdad y engaño al poner en boca del sacerdote egipcio el

89 D. Chr. XI 22 y X 23. Cf. nuestras notas a ése último pasaje en Dión de Prusa, pp. $451, \mathrm{~s}$.

EMERITA. Revista de Lingüística y Filología Clásica (EM) - LXV 2, 1997, pp. 195-220 
discurso verdadero, y en la de Homero, que tenía fama de veraz, el discurso mentiroso.

En el Troyano hallan solución las antinomias emanadas de $\dot{\alpha} \nu \tau \imath \lambda o \gamma i ́ \alpha \iota ~ o$

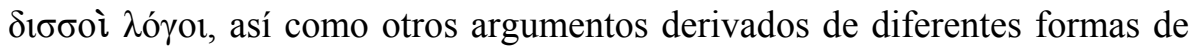
exégesis y de hermenéutica. El problema de la historia de Troya, evidentemente, tiene dos vertientes: una el hecho real y otra la explicación metahistórica de la ficción literaria del propio Homero y de la literatura y hermenéutica posteriores, que, han dado «realidad» mitificando el acontecimiento mismo en dos formas antitéticas.

Homero mintió en su explicación del «hecho real», pero los que afirman que «Homero miente», inventan «otra historia no menos fingida» como hace el sacerdote egipcio. ¿Dónde está la verdad y donde está la mentira? He aquí el dilema. Nos movemos en un un espacio literario en el que los relatos son una creación alegórica y los personajes meras figuras arquetípicas.

\section{Hermenéutica de los arquetipos en Dión de Prusa.}

Uno de los procedimientos más habituales de la hermenéutica de Dión consiste en la recreación de arquetipos o personificación de conceptos abstractos y de virtudes morales, creando una actualización narrativa en torno a ellos, tal y como aparece el nuevo arquetipo de Heracles ${ }^{90}$. En los ensayos de Dión vemos, frecuentemente, al héroe asociado con un personaje, que, en virtud de la exégesis histórica, ha sido llevado al plano de la realidad temporal. Otras veces se trata de personajes realmente históricos. Pero la ruptura de la realidad histórica se produce en virtud de las leyes de la transposición simbólica. Frente a un arquetipo casi divinizado encontramos un prototipo histórico del cinismo: Heracles-Diógenes o Heracles-Antístenes. Ambos pares de personajes o tipos son los dos polos de una misma realidad. El arquetipo y el prototipo sirven para ejemplificar los catálogos de virtudes. Frente a ellos y su conducta encontramos con frecuencia antitipos, en los cuales se personifican los catálogos de vicios. Se trata de dos figuras gemelas o antitéticas que están separadas en el tiempo real, pero coincidentes en la actualización narrativa. Ambas viven dentro del

90 Para una definición de arquetipo literario en la literatura de los siglos I-IV p. C. cf. D. Dawson, Allegorical Readers and Cultural Revision in Ancient Alexandria. Berkeley/ Los Angeles/ Oxford, 1992, pp. 253-254 n. 48.

EMERITA. Revista de Lingüística y Filología Clásica (EM) - LXV 2, 1997, pp. 195-220 
tiempo y de la corriente de la vida histórica.

Heracles en virtud de la exégesis histórica pierde los rasgos más grotescos del viejo mito y, por medio de la alegoría, sus gestos y acciones adquieren una profunda significación moral. Esta tesis encuentra su plena confirmación en el Discurso sobre la virtud o en el Discurso V: El mito africano, en el cual Dión presenta a Heracles como vencedor de los vestiglos de este mundo, cual eran las serpientes africanas. El rasgo más significativo del nuevo arquetipo en el conjunto de la obra dionea consiste en la misión liberadora de pueblos y de individuos por parte del personaje arquetípico. Dión ha superado las formas tradicionales de los viejos relatos de los mitos y cuentos populares y sitúa al personaje en una perspectiva nueva: la del sabio cínico de su tiempo, al presentarlo como encarnación del rey ideal.

En el Discurso sobre la virtud, el héroe se presenta claramente como un modelo de asceta cínico, llevando a cabo sus hazañas con $\pi$ óvo o esfuerzo. Antes de entrar Heracles en la escena, Dión por boca de Diógenes contrapone las figuras del gordo y el flaco. El gordo, que, como se ha dicho, representa a los deportistas, es el antitipo de Heracles y de Diógenes. Frente al ascetismo de Heracles, el gordo se pasa los días comiendo y las noches roncando, es un antitipo de virtud. Por eso, dice Diógenes al gordo habría que trocearlo como a un pescado grueso y cocerlo en salmuera y agua de mar para hacer grasa y ungirse con ella ${ }^{11}$.

En cambio, la figura del flaco, representa en el plano del tiempo histórico y real los rasgos que caracterizan a Heracles como nuevo arquetipo. El flaco

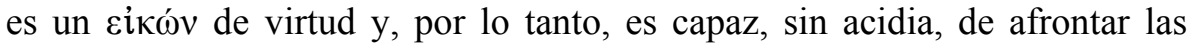
dificultades y de enfrentarse a los deleites de las pasiones, saltando al estadio de la vida, como un corredor, luchador o boxeador, o como el que lanza el disco o la jabalina. Dión había simbolizado la figura del flaco en Antístenes. Al filósofo de Cinosargos, se le hace maestro de Diógenes y discípulo de Sócrates: los tres personajes son modelo de virtud para el sabio cínico. El Sofista por boca de Diógenes nos dice que Antístenes tenía su cintura más delgada que el estrecho talle de una avispa ${ }^{92}$.

El discurso continúa su evolución, desarrollando el paralelismo de

91 D. Chr. VIII 15-16.

92 D. Chr. VIII 1-3.

EMERITA. Revista de Lingüística y Filología Clásica (EM) - LXV 2, 1997, pp. 195-220 
Heracles y Diógenes, dos figuras que el autor conecta. Los contemporáneos de Diógenes no aprecian su esfuerzo por vencer las dificultades y conquistar la virtud. Prefieren ir tras los deportistas, o en busca de riquezas o de placeres. Esto mismo sucedía ya en tiempos de Heracles. Las gentes admiraban más a los atletas como Zetes, Calais o Peleo o a personajes famosos por su belleza o riqueza como Jasón, Cíniras o Pélope, que presumía de hombro de marfil. Consiguientemente, no admiraban, ni sentían compasión por las labores que el héroe con tanto esfuerzo estaba llevando a cabo.

Heracles, situado en un «entonces» que fue el de Diógenes o en un «ahora» que es el del sabio cínico de los tiempos de Dión, dormía a cielo descubierto, pasaba las noches en vigilia y durante el día exhalaba un aliento de hambre, socorriendo a los pobres y castigando a los malvados. El cumplía su misión de liberar al mundo de vestiglos y tiranos. Por eso, mató a Diomedes el tracio, que, muy orondo, estaba sentado en el trono y celebraba diariamente opulentos banquetes, mientras oprimía a los indefensos y a los extranjeros. El héroe, golpeándolo con su maza, lo hizo pedazos como a una vieja cuba ${ }^{93}$.

El hijo de Zeus y Alcmena, en sus peregrinaciones por occidente, mató a Gerión, que se jactaba de ser el más rico y era en realidad el más insolente de toda Hesperia ${ }^{94}$. Además, dio muerte al egipcio Busiris, arrojándolo al suelo, y lo hizo estallar como a un odre hinchado ${ }^{95}$. Arrancó el cinturón de la amazona, cuando, coqueteando con él, quería subyugarlo con su belleza ${ }^{96}$. E incluso a Prometeo, que era un charlatán al que se le inflamaba el hígado, lo curó de su fatua jactancia, dándole su propia inmortalidad y aceptando a cambio la muerte que correspondía a Prometeo ${ }^{97}$. Heracles, símbolo de la vida de acuerdo con la ley de naturaleza, muere en lugar de Prometeo, arquetipo del progreso que hace infelices a los hombres, al apartarlos de una vida de acuerdo con la naturaleza.

Finalmente, cuando se hizo más lento y delgado de lo que era normal en

93 D. Chr. VIII 31.

94 D. Chr. VIII 34.

95 D. Chr. VIII 32.

96 Ibidem.

97 D. Chr. VIII 33.

EMERITA. Revista de Lingüística y Filología Clásica (EM) - LXV 2, 1997, pp. 195-220 
él, Heracles se dio muerte a sí mismo, en un ejemplo bello para la humanidad ${ }^{98}$. Este suicidio de Heracles, imitado dentro del tiempo histórico por Diógenes, cual celeste Can ${ }^{99}$, es sublimado en un texto tan tardío como el bello Himno a la virtud del genial fray Luis de León, en donde se considera al fuerte Alcide como personificación de la elevada virtud ${ }^{100}$. Dión de Prusa interpreta el suicidio de Heracles como un acto de virtud y de amor por la humanidad.

Se comprenderá desde esta perspectiva que la primitiva iconografía paleocristiana representara a Heracles al lado de Cristo y que en uno de sus Himnos Sinesio de Cirene, asiduo lector e imitador de Dión, caracterizara a Jesucristo con un epíteto que pertenece a los trabajos del héroe en su descenso al Hades para vencer a los vestiglos infernales y a los poderes del Tártaro ${ }^{101}$.

Ahora bien, el síwóv de Heracles puede ser contemplado desde distintos

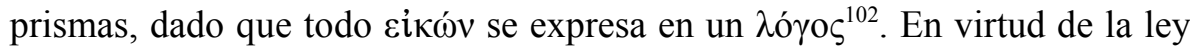
de transposición simbólica, el $\lambda$ óyos se ha transformado en diversos símbolos, sin que la mirada desde diferentes prismas se agote en una sola versión conceptual. Así, por ejemplo, el Héroe en el Discurso I de la Realeza es ante todo la imagen del Poder universal que gobierna el universo, fundamento de todo arquetipo e imagen ideal del hombre. Por eso la principal imagen que Dión ofrece de Heracles es la de rey del universo, que gobierna el mundo en nombre de Zeus, y cuya conducta han de imitar los demás reyes y gobernantes de la tierra. La misión de Heracles no se comprende sin la subida a la montaña mágica de la mano de Hermes, donde tiene lugar una encrucijada de caminos, la elección entre Realeza y

98 D. Chr. VIII 34 M. Simon, Hercules et le christianisme, Paris, 1955 y J. N. D. Kelly, Early Christian Creeds, Londres, 1950, pp. 378-383.

99 Cércidas de Megalópolis, poeta cínico del siglo III a. C., en sus Meliambos o breves poemas líricos cuyo contenido era conversacional o satírico denomina así a Diógenes de Sínope, Fr. 1 en ed. de I.U. Powell, Collectanea Alexandrina, Oxford, 1973, pág. 202.

100 Fray Luis de León. Obras Completas, ed. de Félix García, Madrid, 1951, p. 745.

101 Synesii Episcopi Cyrenes Opera que exstant omnia, Paris, 1612, IX, vv. 13-15, pp. 346-348; Ch. Lacombrade, Synésios de Cyrène. Hymnes, Paris, 1978, VIII, 21 Para la supervivencia de Dión en Bizancio cf. A. Brancacci, Rhetorikè philosophousa, Dione Crisostomo nella cultura antica e bizantina, coll. Ellenchos 11, Nápoles, 1985.

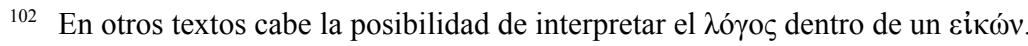

EMERITA. Revista de Lingüística y Filología Clásica (EM) - LXV 2, 1997, pp. 195-220 
Tiranía $^{103}$. Como resultado de la elección por el bien y la virtud, Heracles tiene que acompasar su conducta con las virtudes que conlleva la Realeza.

En la montaña mágica, Heracles ha elegido la doncella del vestido blanco, símbolo de la pureza de conducta, una Realeza, que está acompañada de Justicia, Equidad, Paz y Derecho, virtudes que son el fundamento de las sociedades humanas. El Héroe tendrá en este mundo una vida laboriosa y ascética, llena de trabajos y dificultades, para que impere la justicia, la paz y el derecho. Así lo exigía su fidelidad a la opción fundamental que hizo en la montaña. Rechaza, en cambio, a los poderes del mal simbolizados en la Tiranía, vestida con rico traje multicolor, símbolo de las múltiples formas con que se disfraza la perversidad. Tiranía estaba acompañada de Hybris, Ilegalidad y Sedición, que prometían al héroe una vida fácil y llena de deleites. Heracles durante su trayectoria en el tiempo histórico y real, con sus trabajos está luchando continuamente contra los tiranos de este mundo.

\section{Epílogo.}

Con posterioridad a Dión de Prusa la hermenéutica griega se complica. Partiendo de la significación usual de las palabras, Clemente de Alejandría, Proclo o Porfirio procuran trascender las significaciones metafóricas y alegóricas. Siguiendo un esquema básicamente platónico las significaciones usuales y metafóricas de las palabras pueden ser llevadas más allá del plano inteligible, a un $\lambda$ ó ${ }^{\circ} \varsigma$ que es un enigma o un misterio. Encontramos en Plutarco la afirmación de que la esencia del saber mítico, al cual Estrabón llamó «género teológico», es de caracter enigmático. Ahora bien el problema planteado por un enigma no se agota en la respuesta. Es más, la solución o respuesta contenida en el logogrifo suele ser el verdadero enigma ${ }^{104}$, como expone Dión al tratar de Edipo ${ }^{105}$. En el llamado género teológico la imagen de un arquetipo adquiere un simbolismo polivalente. El $\lambda$ ó $\gamma$ $\varsigma$ «ciriológico» o «tropológico», que se expresa en una «fabula», asciende en virtud de una parábola, de una adivinanza o de un misterio desde lo «tropológico» a lo «enigmático», creándose de esta forma un mensaje hermético o

103 Ver nuestro comentario a Or. I 66-83, en Dión de Prusa, pp. 155-161.

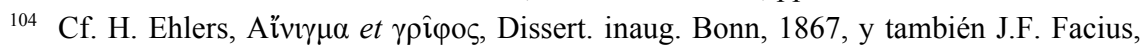
De aenigmate et gripho, Jena, 1879.

105 D. Chr. X 25, 29-32.

EMERITA. Revista de Lingüística y Filología Clásica (EM) - LXV 2, 1997, pp. 195-220 
«jeroglífico». Estamos ante la exégesis mística del llamado neopitagorismo o neoplatonismo o ante los enunciados de muchos Padres de la Iglesia Griega, que nos hablan del misterio trinitario a través de flores, plantas y otras

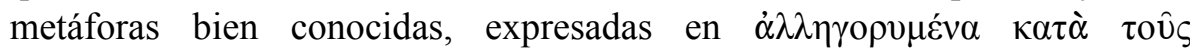
$\alpha i v v \gamma \mu o v \varsigma^{106}$.

Probablemente tenía razón Protágoras de Abdera, cuando en el diálogo platónico que lleva su nombre, afirmaba que el saber de todas las artes y de las ciencias está oculto bajo un velo o una máscara. Sin embargo, la mente humana puede ir más allá de los enigmas a que llega el saber científico y

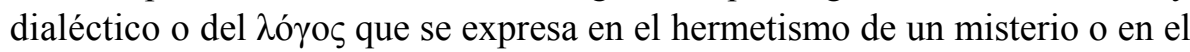
leguaje de la mística. También estas formas de $\lambda o ́ \gamma o \varsigma$ pueden perder toda su magia y mística al ser llevadas por la filología al plano ciriológico y ser reducidas a meros elementos. Estos $\sigma \tau 0 \iota \chi \varepsilon i \alpha$ pueden ser reordenados conforme a estructura y funciones. Se trata del $\lambda$ ó $\gamma$ os que asciende y desciende por diversos planos, a través de un $\gamma \rho \hat{i} \varphi$ os tan delgado como el hilo de una caña de pescar, y que sumerge a la mente humana como en una noria, dando siempre vueltas sobre la misma rueda. No obstante el mismo $\lambda$ óyos posibilita la salida desde el eterno círculo al campo de la libertad, pero en ese supuesto el fundamento y sostén que evita el desequilibrio está en el propio $\lambda$ óyos.

GASPAR MOROCHO GAYO prensa)

106 G. Morocho Gayo, «Manuel Moscópulo y la polémica religiosa de su tiempo». (En EMERITA. Revista de Lingüística y Filología Clásica (EM) - LXV 2, 1997, pp. 195-220 